Pléh Csaba*

\title{
A KATOLIKUS HAGYOMÁNY A MAGYAR PSZICHOLÓGIA KORAI SZAKASZÁBAN: HARKAI, DIENES, SCHÜTZ
}

\begin{abstract}
A dolgozat a katolikus hátterú kora 20. századi magyar pszichológusok szemléletének bemutatásán keresztül a mellett érvel, hogy a magyar kutatók sem egyetlen egységes változatát fogalmazták meg a „katolikus pszichológiának”, hanem különbözó módon közelítettek a szaktudományos pszichológia kérdésköréhez. Ugyanakkor az ismertetett szerzók mind a szaktudomány önállósága mellett érveltek, s a modernizációs felhang keretében jellemző rájuk a funkcionalizmus és az arisztotelészi felfogás összekapcsolása, a gondolkodáslélektan elótérbe helyezése, az integratív személyiség felfogás és a gyakorlati funkcionalizmus: a nevelési reform és a gyermekközpontú, a fegyelmezó neveléstól eltéró nevelési eszmények meghonosítása. A katolikus szellemi életben megnyilvánuló különbözó áramlatok - politikai és eszmei áramlatok - megtalálják a saját helyüket a katolikus pszichológián belül. Fontos mozzanat ezek mögött mai szempontból az a felismerés, hogy nem volt szükségszerû ellentmondás a személyes katolikus meggyôződés, sôt a katolikus értelmiségi szerepvállalás és a modern pszichológia hirdetése, akár a kísérleti pszichológia piedesztálra állítása között. A különbözô alternatívákban különböző személyiségek és értékbeli hozzáállások jelennek meg a katolikus táboron belül is.
\end{abstract}

Kulcsszavak: katolicizmus, funkcionalizmus, gondolkodáslélektan

Dolgozatom célja nem a magyar katolikus pszichológiai hagyomány részletes elemzése, nem is annak felmutatása, hogy az egyes tárgyalt életmúvek pontosan hogyan illeszkednek a korai magyar pszichológia egészébe. Igazi mondanivalóm fóként azzal kapcsolatos, hogy a katolikus hátterú, illetve hívô katolikus világnézetú, az akkoriban, a 20. század elsô harmadában bontakozó modern pszichológia mozgalmába bekapcsolódó magyar kutatók sem egyetlen egységes változatát fogalmazták meg az úgymond „katolikus pszichológiának”, hanem különböző módon közelítettek a szaktudományos pszichológia kérdésköréhez. Ennek során néhány kiválasztott életmúvet érintek csak. Nem véletlenül éppen óket, hanem azért, mert munkásságukban nemzetközi értelemben is jellegzetes hozzáállást képviselnek. Rövid dolgozatomnak van némi ismeretter-

\footnotetext{
* Prof. Pléh Csaba

BME Kognitív Tudományi Tanszék

1111 Budapest, Stoczek u. 2.

E-mail: pleh@cogsci.bme.hu
} 
jesztố szándéka is. A magyar katolikus pszichológiai hagyomány a nemzetközi köztudatban igencsak elhalványult. Misiak és Stadt (1954), valamint Sexton és Misiak (1966) kitûnó áttekintései például semmit sem tudnak rólunk és az itt elemzett szerzókról.

A 20. század elején a pszichológiában megjelenó katolikus szerzóknek, illetve a pszichológia és a katolikus világ közti kölcsönhatásnak különbözó változatai voltak. (Kétségtelen, hogy ezek a változatok összefüggésben voltak a katolikus megújulási, illetve konzervatív szellemi mozgalmak kettôsségeivel, ennek részletei azonban most messze vezetnének, ezért ezzel nem foglalkozom.) Az egyik változat - egyszerúen fogalmazva - a tudománytól való félelemból fakad: valójában riasztja az a távlat, hogy az emberi elme (a „lélek") elemzés tárgyává válik, s a természettudományos elemzó, az ember lelki bensőségét mintegy lealacsonyító felfogással szemben védelmezni óhajtja a mentalizmust, a lélek fogalmát és a karosszék-filozófiai pszichologizálást, a kategóriákból származtatott mindentudás félrevezetó eszményét. Ez a félelmi reakció megjelent egyébként Magyarországon is. Kozáry Gyula (1898) kismonográfiája például a pozitivizmusban és redukcionizmusban elmarasztalt múlttal a szubsztanciális lélekfelfogást állítja szembe, még a 19. század utolsó éveiben is. Fontos azonban látnunk, hogy ezzel a félelmi reakcióval egyidejúleg jelentek meg különböző törekvések, amelyek lényegében egy sajátos kettôs igazságelmélet felújítására törekedtek az emberi sorsok és a tudománymúvelés köznapi gyakorlatában; vagyis arra, hogy a hitet és a hit szempontjából központinak tartott mozzanatra, a lélekre vonatkozó új tudományosságot egymással összeegyeztessék. Olyan modernizációs törekvések voltak ezek, amelyek a hit és a tudomány világa közötti közvetlen áthallások nélkül dolgoztak. Hogy csak egy olyan példát említsek, akit életmúve nagysága miatt itt nem elemzek: Kornis Gyula 1917-ben megjelent hatalmas, ezerháromszáz oldalas összefoglaló pszichológiai munkájában egyáltalán nem foglalkozik a hittételekben található lélekproblematika és az általa ismertetett számos irányzatának megfelelóen áttekintett, modern, analitikus kísérleti pszichológia viszonyával. Kétségtelen, hogy szimpátiái - különösebben késóbbi munkásságában - a szellemtudományos pszichológia felé húzták, ami összhangban van bizonyos lelkileges doktrínákkal, ezzel együtt magának a kísérleti lélektannak az ismertetése során nincs áthallás az ô közismert katolikussága és az új, a hagyományos elképzeléseket megkérdôjelező lélektani felfogás között.

Ennek a modernizációs felhangnak a keretében jelentek meg a nemzetközi pszichológiában is különbözó katolikus próbálkozások a modern pszichológia elméleti értelmezésére. Három ilyen törekvés figyelhetô meg a korabeli európai pszichológiában; mindhárom jelen van Magyarorszá- 
gon is - éppen erról szól e tanulmány -, és mindhárom valójában mindmáig érezteti hatását.

- Funkcionalizmus és arisztotelészi gondolatok összekapcsolása. A karteziánussal, mint egyik katolikus hagyománnyal szembeállított tomista-arisztotelészi hagyomány összhangját fedezik fel sokan a modern funkcionalista pszichológiával.

- Lágy intencionalitás: a Denkpsychologie a würzburgi iskola gondolkodás-lélektani munkásságának összekapcsolása a modern pszichológia Brentano által kifejtett programjával. Ennek lényege, hogy a lelki jelenség definiáló jegyei nem testetlenségében, hanem tárgyi vonatkozásában keresendók.

- A gyakorlati funkcionalizmus: a nevelési reform és a gyermekközpontú, a poroszos, analitikus és fegyelmezó neveléstól eltérô nevelési eszmények meghonosítása.

\section{HARKAI SCHILLER PÁL (1908-1949) FUNKCIONALIZMUSA}

Harkai munkássága szigorú értelemben nem kapcsolódik a „katolikus pszichológia" hagyományához, eszmeileg mégis ő testesíti meg az elsó változatot, melyben az arisztotelészi funkcionalizmus és a kísérleti pszichológia eszmerendszere kapcsolódik össze. Ebben a tárgyi értelemben tekinthetố munkássága sajátos katolikus fejleménynek - azon az élettörténeti körülményen túl is, hogy a katolikus szellemi és értelmiségi életbe messzemenóen beágyazva fogalmazta meg nézeteit -, s így a modern magyar pszichológia egyik, mára egyre világosabban alapvetôvé váló hagyományát testesítette meg. Harkai, mint Marton Magda (1996) és Dewsbury (1994a, 1994b, 1996) gondos elemzései világosan feltárták, nemzetközi értelemben is úttörő kutató volt, amikor megpróbálta összekapcsolni az összehasonlító lélektani szemléletet a magatartásszerveződés sajátos jeltani és alaklélektani felfogásával. Ez megjelent kísérleti munkáiban is, melyekkel sokat tett az emlős és fóemlős cselekvésszerveződés tisztázásáért. Történetileg, a magyar pszichológia egészét tekintve, az ô érdeme volt, hogy a budapesti bölcsészkaron sikerült összekombinálnia a pszichológia legfóbb hibridizációs mozzanatának (Ben-David és Collins 1966) megfelelóen az ismeretelméleti, filozófiai kérdésfeltevést a természettudományok kísérleti módszertanával. Harkai Schiller Pál volt az, aki Révész Géza rövid ideig tartó próbálkozása után sikeresen „becsempészte” a bölcsészet világába a kísérleti pszichológiát.

Az itt elemzett katolikus pszichológiai hagyomány szempontjából mun- 
kásságának két fontos mozzanata van. Ezeket anélkül emelem ki, hogy megkérdójelezném kísérletezói nagyságát és nemzetközi jelentôségét az összehasonlító pszichológiában. Az egyik mozzanat az arisztotelészi funkcionalizmus elméleti, pszichológiai igényú felújítása. Harkai szerint - mint A lélektan feladata (1940, új kiadás 2002) mutatja -, a hagyományos karteziánus dualizmus gondja az „emeletes emberkép” - az a felfogás, amely a testi folyamatokkal egyenlő absztrakciós szinten tételezi fel a mentális világ külön realitását. Ezzel egy olyan biológiai emberképet állít szembe, mely lényegében az arisztotelészi hagyomány felújítása, s mely szerint test és lélek, fiziológia és pszichológia nem külön emeletei a teljes emberképnek. A lelki jelenség az ember testi folyamatainak sajátos szervezésmódja. Ez az a különleges funkcionalizmus, mely a katolikus pszichológia történetében rokonítja ốt az elózố nemzedékból a belga neotomista „modernizátor”, Mercier (1897/1926) munkásságával, aki korának kísérleti pszichológiáját kiválóan ismerve fogalmazott meg egy határozott elképzelést a test-lélek egységéról, szemben a wundt-i kétféle szemlélet doktrínával, mely sajátosan modern körülmények közt próbálta felújítani a karteziánus dualizmust. Harkai számára is kulcskérdés, hogy a wundt-i szemlélet és a karteziánus dualizmus közt folytonosság van. Elméleti munkájában a pszichofizikai parallelizmus „heurisztikus elvét”, a Wundt-követók számára oly fontos módszertani doktrínát mint az ontológiai karteziánus dualizmus folytatását interpretálja. Wundt legfóbb gondja Harkai szerint - s ez már túlvezet az arisztotelészi megfontolásokon egy tágabb funkcionalista keretbe -, hogy nem tud mit kezdeni a viselkedést és mentális folyamatokat meghatározó környezeti erók - a "mező" - problémájával. A cselekvés szerveződése az egységes biológiai lény és a környezet közti viszonyban értelmezendó. Az élólények motivációs rendszere csak az evolúciós környezetben kap értelmet és nem interpretálható pusztán élmény és belsô fiziológiai folyamat összefüggésrendszerében.

Ez ad sajátos ízt Harkai nézeteinek a pszichológia egységéról. Számára az egység kulcsa az, hogy az állati viselkedés cselekvéses mozzanatait, motivációs oldalát, a lelki jelenségek valamire irányulását, intencionalitását és egészleges szervezódését kell előtérbe állítanunk. Ennek a pszichológiának a mozgatói Harkai $(1940,1944,1946)$ számára a kor hagyományából Brentano (1874, 1911/1994), azután Karl Bühler (1927) elképzelései a pszichológia jeltani egységéról, mely szerint minden állati és emberi viselkedésre jellemző a célirányosság és a jelek által irányítottság, valamint az alaklélektani iskola jel-gestaltokat hangsúlyozó felfogása. Minden viselkedés célirányos, ugyanakkor tárgyi tartalmai vannak és egészleges szervezôdésú, s ez érvényes a legegyszerúbb állati viselkedé- 
sektól az emberi nyelvig. Ez a hangsúly arra hivatott, hogy meghaladja a motivációs hangsúlyú pszichoanalitikusok, a megismerés-hangsúlyú kísérletezók és a viselkedéselemzó behavioristák ellentmondásait. Ezt hirdeti Bühler, s Harkai is.

Modern szintézispróbálkozás volt Harkai munkája, amelyet a hetvenes évektól kibontakozó kognitív tudományi szemlélet büszkén vállalhat értékes magyar hagyománynak (vö. Pléh 1998), s melynek értékét kísérleti eredményei mellett az is megadja, hogy az arisztotelészi funkcionalizmus felújítását összekapcsolja az állati viselkedés komplex elemzésére való törekvéssel. Ezt azért fontos hangsúlyozni, mert ugyanakkor a kognitív tudományi funkcionalizmus egy szintén Arisztotelészre hivatkozó sajátos iránya, a hatvanas években Putnam (1960) és Fodor (1968) munkásságával elinduló gépi funkcionalizmus sokkal kevésbé lát folytonosságot a 19. század végétól elinduló evolúciós funkcionalizmus és az új "gépies alapú" arisztotelészi értelmezés között. A kognitív tudósok egy része számára a funkcionalizmus lényeges mozzanata a komputációs liberalizmus: az a hit, hogy különböző lényeknek lehetnek gondolati szervezódéseik, melyek közül logikailag a gépek sincsenek kizárva, és nem érdekli óket a klasszikus európai funkcionalista hagyomány olyan problematikája, mint az állati viselkedés szervezódési szintjeinek kérdése vagy az egyéni különbségek biológiai interpretációja. Harkai még sokkal határozottabban biológiai funkcionalista; ebben az értelemben számomra ő a sokszor filozófiai behavioristának bélyegzett Ryle (1949/1998) rokona. Ryle, amikor a karteziánus színház kategóriahibáit elemezte, egy biológiai típusú lehorgonyzását szerette volna létrehozni annak, amit azóta elmefilozófiának nevezünk (persze, akkor éppen a behaviorista szóhasználati közeg révén ezt még nem nevezték elmefilozófiának). Ryle sokkal lágyabb és nyitottabb volt a tényleges biológiai folyamatok értelmezése irányába, mint a száraz kognitivisták egy része. Harkai ehhez a kifejezetten biológiai funkcionalista irányhoz tartozik.

\section{EGY GYAKORLATI FUNKCIONALISTA KATOLIKUS SZERZÖ: DIENES VALÉRIA (1879-1978)}

Dienes Valéria a magyar szellemi élet különleges, kiemelkedó csillaga, aki egyszerre jelent fontos vonatkoztatási terepet a magyar filozófiatörténet, a neveléstudomány és a katolikus eszmetörténet, de akár a táncmúvészet kutatói számára is. Élettörténetének közismert mozzanatait csak felsorolásszerúen említem. Ó volt az elsó nó, aki filozófiai doktorátust szerzett 
a budapesti egyetemen, ráadásul esztétikából és matematikából. Egyszerre volt hosszú élete során a funkcionalista nevelési eszmények propagátora, Bergson magyarországi értelmezóje, úgy is mint Bergson személyes tanítványa, s úgy is, mint avatott Bergson-fordító (Bergson 1889, 1907, 1913). Ó volt egy különleges táncmúvészeti mozgalom, az orkesztika elindítója, és ebben a minőségben Raymond Duncan tanítványa és talán újraértelmezóje, és ugyanakkor egy katolikus szellemi inspirátor a tánc kifejezô értének megtalálásában.

Közismert az is, hogy - mint sokszor maga is leírja (Dienes 1983) - korai éveiben éppen a radikális társadalmi és filozófiai mozgalmakhoz kapcsolódva meglehetôsen határozott pozitivista és „materialista” felfogást képviselt, ezt azonban több világnézeti megrendülés követte. Ennek első forrása Bergson volt, akinek idealizmusa meglehetôsen nagy hatást gyakorolt Dienes filozófiai és pszichológiai nézeteire a század elsó évtizedében. Egy újabb, személyes drámával is motivált szellemi váltás révén Dienes azután visszatért a katolicizmushoz, és további életében a filozófiai munkálkodást a katolikus hitéleti tevékenységgel összekapcsolva dolgozott.

Pszichológiatörténeti szempontból két mozzanat érdekes hosszú munkásságában. (Vannak persze igen fontos oldalági mozzanatok is; ô volt nemcsak Bergson fordítója és propagátora, hanem a hatvanas években John Locke magyar értelmezője is, akinek különleges terminológiájában ismertük meg az empirista hagyományt, sôt, Locke jeltanának egyéni értelmezését is adta /Dienes 1981/). Bergsoniánus ihletésú munkáiban (Dienes 1923) a mentális élet konstruktív mozzanatainak jelentôségét hangsúlyozza és a "belsó mozgás” koncepcióját. Számára Bergson egy különleges cselekvésfilozófus, akinek emlékezetelmélete (Bergson 1896) és késôbbi munkája (1907) is azt állítják elôtérbe, hogy a mentális világ nem pusztán passzív összegzése szenzoros partikuláknak; a lélek lényege a belsô integratív mozzanat, az a sajátos, értelemadó plusz, amely megkülönböztet minket puszta kiszolgáltatott lény voltunktól. Kulcsmozzanat ez Dienes Valéria számára, s a pszichológus szaktörténész ebben láthatja a szellemi összekötó kapcsot bergsoniánus gondolatai, funkcionalista szemlélete és sajátos aktivista katolicizmusa között. Ha értelmezni akarjuk múvét a katolikus pszichológiai hagyományok szempontjából, számára az affinitást katolicizmus és modern pszichológia között az adja meg, hogy nem a passzív elme és a passzív szervezet koncepciójából indul ki.

A bergsoni hagyomány mellett ố volt az, aki fordításaival és reformiskolai involváltságával sokat tett azért, hogy a századeló francia pedagógiai funkcionalizmusa gyökeret verjen Magyarországon is. Binet (1916) fordítójaként ô képviseli azt az elképzelést, amely szerint a nevelésnek a 
gyermek érdekeiból és a gyermek megismeréséból kell kiindulnia. A gyermeknek mint sajátos önkibontakozó rendszernek kellene segítenie a nevelés folyamatát, a nevelés nem kívülról oktrojált, kész rendszerek puszta interpretációja kellene legyen.

Pszichológiai felfogása egészének megértésére tanulságos egy áttekintô munkája. 1914-ben egy különlegesen érdekes rövid brosúrát publikált a Galilei Füzetekben, a kor közismert progresszív baloldali fórumán, a Mai lélektanról. (Részleteit lásd még Pléh 1987.) Furcsa szintézis ez, amelyben egyszerre szerepel Ivan Pavlov (!) és a würzburgi gondolkodáslélektan, mint a pszichológia megújítói. Mi lehet közös ilyen - mai szemléló számára - furcsán távolálló irányzatokban? Hiszen az egyik a viselkedéselvú, a másik pedig a mentalisztikus szemlélet egyik kiindulópontja lesz a 20. századi pszichológiában. Dienes számára a közös mozzanat a rejtett tényezók és a funkciók elótérbe állítása. Rejtett tényezókön azt érti, hogy mentális életünk számos olyan szerveződést mutat, amelyek közvetlenül nem áttetszók, nem transzparensek az önmegfigyelő ember számára. A gondolkodást olyan rejtett szabályok irányítják - hangsúlyozza a würzburgi iskola -, amelyeket önmagukban nem tudunk megismerni, csak termékeiken, gondolati eredményeiken keresztül. Pavlov pedig azt állítja elótérbe, hogy a tanulásnak is vannak olyan automatikus algoritmusai, melyek közvetlenül nem áttekinthetóek. Mindez olyan szintézist sugall Dienes Valéria áttekintésében, ami a lélektant a rejtett szervezódések sajátos tudományaként állítja elótérbe, ahol az alaklélektani gondolkodás gyôzelmét jóval megelôzve, a szerveződésen van a hangsúly.

\section{SCHÜTZ ANTAL (1880-1953): A KATOLIKUS DOGMA ÉS A MODERN PSZICHOLÓGIA}

Míg Harkai a bölcsészkaron meghonosodó kísérleti hagyomány, Dienes pedig a nevelési mozgalmakban megtestesülő funkcionalista hagyomány mintaadó képviselóje volt a magyar pszichológiában, Schütz Antal különlegességét az adja, hogy - szemben például Kornissal, aki háttérben hagyja, hogy milyen viszony is kell legyen a katolikus hittétel és a modern pszichológiai hitvallás között - Schütz számára pontos tisztázást igénylő viszony keresendő e két hitvallás vagy tényező között. Fiatal korában Schütz a kor kísérleti gondolkodáslélektana, a würzburgi iskola ihlette kutatással szerzett fokozatot kísérleti pszichológiából (l. erról Schütz 1942). Az asszociatív felidézést meghatározó rejtett tendenciákat vizsgálta. Fontos itt emlékeznünk rá, hogy a würzburgi iskola általános gon- 
dolatmenete az, hogy egyrészt a mentális tevékenységet számos, nem képzetes mozzanatok - beállítódások, attitúdök - irányítják, másrészt az egyén gondolkodásának jellegzetes szabályozottságai vannak - a logika pszichológiai értelmezést is kap -, harmadrészt pedig ezek a mozzanatok úgy értelmezendőek, hogy a mentális élet valami önmagán kívülire mutat, jellegzetessége az intencionalitás. Ez a brentanói hagyomány az, amely Schütz számára lehetôvé teszi a logicista würzburgi pszichológiai kutatások összekapcsolását a katolikus eszmerendszerrel.

Schütz a budapesti egyetemen nem pszichológusként vert gyökeret, hanem a katolikus dogmatika professzora lesz. Az én olvasatomban olyan szemléletet képvisel, amely szerint a modern természettudományok (ebbe beleértve a pszichológiát is) és a katolikus eszmerendszer viszonyában nem kettốs igazságra kell törekedni, hanem mindig a dogmatikának kell vezetnie, mintegy iránytút adnia a mentális élet empirikus tanulmányozása felé. Sajátos szövetséget próbál teremteni a katolikus dogmatika és a korabeli pszichológia - mai szemmel hermeneutikai felhangú - kritikája között (Schütz 1944). Olyan kritika ez, amely a 20. század végén megjelenik például Ricoeur éppenséggel protestáns alapú kriticizmusában a mai kor neurobiológiája és pszichológiája felett (lásd például Changeux és Ricoeur 2000), de számos laikus, nem vallásos formában is - pl. Rom Harré (1989) múveiben vezetô ideológiai kritikája mindmáig a kísérleti pszichológiának. Ugyanakkor Schütz munkája azt is jól tükrözi, hogy a katolikus pszichológiai hagyományban milyen különleges szerepe van s itt természetesen Brentanóra is gondolhatunk - a logikai vizsgálódásnak. (L. erról Mezei 1994.)

Schütz pszichológiai nézeteinek kiindulópontja, hogy a tudományos pszichológiát (ez a kiindulópont fóleg késóbbi munkásságára, a harmincas évek végére jellemzó) kritikusan kell kezelni, s ennek a kritikának szilárd alapot adhat a katolikus dogma, elsósorban egy határozott tomista értelmezése a lelki jelenségeknek. Nem tanulság nélküli azonban ez a nézetrendszer a szaktudományos pszichológia számára sem. Schütz kiindulópontja - mint utaltam már rá - a gondolkodás aktuselmélete, az a hit, hogy a gondolkodási folyamatok, összhangban a würzburgi iskola nézeteivel, nem tekinthetók puszta szenzoros akkumulációnak, hanem a gondolkodás lényegét a megismeró alany sajátos múveletei, cselekvései alkotják. Ez a cselekvó mozzanat lesz - a dogmatikus elvek értelmezésének megfelelóen - a kulcs ahhoz, hogy az elmét vagy lelket ne redukálhassuk elementáris folyamatokra.

Schütz (1944) késóbbi munkáiban - már ami a pszichológiai relevanciát illeti - érdekes részletes kirándulásokat tett a pszichológia ideológiai kritikájának irányába is. A pozitivizmust és az evolúciós doktrínát mint 
terméketlen és ténybelileg tarthatatlan nézetrendszereket bírálja. Ugyanakkor különleges vonzalmat érez a kor karakterológiai mozgalmai iránt. Egyik munkájában, mely akadémiai székfoglalója is (Schütz 1941), részletesen megpróbálja kifejteni, hogy a logikai iskolák, vagy irányzatok eltérései a kutatók személyiségtípusával függnek össze. Ahogyan vannak gondolkodástípusok, ugyanúgy vannak a tudományos iskolákban megnyilvánuló gondolkodástípusok is. A logikai atomizmus például egy jellegzetes, részekre szabdaló személyiségalkattal, míg a logikai holizmus inkább az egészleges világnézettel kapcsolódik össze. Világnézet jelenik meg magukban a logikai iskolákban, a személyiség szúrójén keresztül. A személyiségre használt kategóriák és az arisztotelészi kategóriatan szintéziséból indul ki ez a sajátos ízú próbálkozás. Mindkét törekvése, mind a logikai irányzatok személyiséglélektani interpretációja, mind pedig az arisztotelészi típusú személyiséglélektani törekvés Schütz számára annak az alátámasztása, hogy a pozitivista és redukcionista, szétszabdaló pszichológiákkal szemben a személyiség egységéból kiinduló szintetikus felfogások teremtik meg az összhangot a lélek- vezérelvú katolikus gondolkodásmód és a modern pszichológia között.

\section{ÖSSZEFOGLALÁSKÉNT}

A néhány magyar törekvés bemutatása is azt sugallja, amit Sexton és Misiak (1966) összefoglaló könyve is megmutatott: nincsen egységes és egyedi „katolikus pszichológia”. A katolikus szellemi életben megnyilvánuló különbözó áramlatok - politikai és eszmei áramlatok - megtalálják a saját helyüket a katolikus pszichológián belül. Ennek megfelelốen vannak a katolikus modernizációval és a katolikus dogmatika revideálásával, illetve újra középpontba állításával összhangba hozásra törekvő, magukat katolikusnak tartó vagy általunk katolikusnak besorolható munkák a kibontakozó modern magyar pszichológiában. Fontos mozzanat ezek mögött mai szempontból az a felismerés, hogy nem volt szükségszerú ellentmondás a személyes katolikus meggyőzódés, sôt katolikus értelmiségi szerepvállalás és a modern pszichológia hirdetése, akár a kísérleti pszichológia piedesztálra állítása között. A különbözố alternatívákban különböző személyiségek és értékbeli hozzáállások jelennek meg a katolikus táboron belül is.

Vannak azonban rejtett közös mozzanatok a különbözó, magukat katolikusnak sorolható felfogások között. Nehéz elképzelni olyan katolikus pszichológiát, mely egyértelmúen empiricista lenne, egyértelmúen csupán elemi szenzoros morzsák akkumulációjaként képzelné el a men- 
tális múködést. Hasonló rejtett közös intellektuális elv a 20. századi magyar katolikus pszichológiában a hol programként kifejtett, hol csak másodlagosan, feltételezésként jelenlevô arisztotelészi funkcionalizmus, továbbá a mentális élet integratív mozzanatainak elótérbe állítása - legyenek ezek jel-gestaltok, mint Harkainál vagy a személyiség integráló szerepe, mint például Schütznél -, valamint az a hit, hogy az egységet kell keresnünk mind az emberi személyiségben, mind pedig a pszichológia tudományában is. További jellegzetes rejtett mozzanat - és ez az integratív felfogással is összefügg - az aktusnak, a cselekvố lelki vonatkozásoknak az elótérbe állítása, s a mentális élet önmagán túlmutató jellegzetességeinek feltételezése. Ez történhet viselkedéses alapon, ahol az állati és emberi viselkedés közti kontinuitást hangsúlyozzuk egy evolúciós felfogásban, mint Harkai munkásságában, de történhet kifejezett katolikus dogmatikai alapon; a gondolatok másra való utalása végül is rejtett módon a vallási típusú transzcendencia pszichológiai megfelelóje lesz, mint Schütznél.

\section{Irodalom}

Ben-David, J., Collins, R. (1966): Social factors in the origin of a new science: the case of psychology. Amer. Sociol. Rev., 31: 451-465.

Bergson, H. (1889/1923): Idô és szabadság. Franklin, Budapest. Hasonmás: Universum, Szeged, 1990.

Bergson, H. (1896): Matiere et mémoire. Alcan, Párizs. Hivatkozások a kritikai kiadás alapján: Oeuvres 1959, Presses Universitaires de France, Párizs.

Bergson, H. (1907/1930): Teremtô fejlődés. Magyar Tudományos Akadémia, Budapest (Hasonmás: 1987).

Bergson, H. (1913): A nevetés. Révai, Budapest. Legújabb kiadás: Gondolat, Budapest, 1996.

Binet, A. (1916): Az iskoláskor lélektana. Franklin, Budapest.

Brentano, F. (1874): Psychologie vom empirischen Standpunkt. Meiner, Lipcse.

Brentano, F. (1911/1994): Az erkölcsi ismeret eredete. Kossuth Kiadó, Budapest.

Bühler, K. (1927): Die Krise der Psychologie. Fischer, Jéna.

Changeux, J-P., Ricoeur, P. (2000): A természet és a szabályok. Osiris, Budapest.

Dewsbury, D. A. (1994a): Paul Harkai Schiller. Psychological Record, 44: 307-350.

Dewsbury, D. A. (1994b): Harkai Schiller Pál és munkássága. Pszichológia, 1: 377-398.

Dewsbury, D. A. (1996): Paul Harkai Schiller: The Influence of his Brief Carrer. In Kimble, G. A., Boneau, C. A., Wertheimer, M (eds.): Portraits of Pioneers in Psychology. Mahwah, NJ., Lawrence Erlbaum, 281-293.

Dienes V. (1914) A mai lélektan fóbb irányai. Galilei Füzetek, Haladás, Budapest.

Dienes V. (1923): Bergson lélektana. In Bergson, H. (1923): Idô és szabadság. Franklin, Budapest, 7-49.

Dienes V. (1981): A szimbólika fóbb problémái. In Gráfik I., Voigt V. (szerk.): Kultúra és szemiotika. Akadémiai Kiadó, Budapest, 15-27.

Dienes V. (1983): Visszaemlékezés. In Hajnalvárás. Szent István Társulat, Budapest, 16-51. 
Fodor, J. (1968): Psychological explanation. Random House, New York.

Harkai Schiller P. (1940): A lélektan feladata. Magyar Tudományos Akadémia, Budapest. Új kiadás: Osiris, Budapest, 2002.

Harkai Schiller P. (1944): Bevezetés a pszichológiába: A cselekvés elemzése. Pathéon, Budapest.

Harkai Schiller P. (1946): Lélektani Tanulmányok Ranschburg Pál emlékére. Pázmány Péter Tudományegyetem Lélektani Intézete, Budapest.

Harré, R. (1989): Vygotsky and artificial intelligence: What could cognitive psychology possibly be about? Philosophical Psychology, 2: 389-400.

Kornis Gy. (1917): A lelki élet. I.-III. Magyar Tudományos Akadémia, Budapest.

Kozáry Gy. (1898): Wundt rendszerének ismertetése és kritikája. Atheneum, Budapest.

Marton L. M. (1996): Harkai Schiller Pál tudományos szemlélete 30 év néhány tudományos felismerése tükrében. Pszichológia, 16: 115-131.

Mercier, D. (1897/1926): Les origines de la psychologie contemporaine. Louvain, Alcan, 3. kiadás.

Mezei B. (1994): Pszichologista volt-e Franz Brentano? In Brentano, F. (1994): Az erkölcsi ismeret eredete. Kossuth Kiadó, Budapest, 5-38.

Misiak, H., Stadt, V. M. (1954): Catholics in Psychology: A Historical Survey. McGraw Hill, New York.

Pléh Cs. (1987): A pszichológus Dienes Valéria. Pszichológia, 7: 431-451.

Pléh Cs. (1998): Hagyomány és újítás a pszichológiában. Balassi, Budapest.

Putnam, H. (1960): Minds and machines. In Hook, S. (ed.): Dimensions of mind. Collier Books, New York.

Ryle, G. (1949/1998): A szellem fogalma. Osiris, Budapest.

Schütz A. (1941): Logikák és logika. Magyar Tudományos Akadémia, Budapest.

Schütz A. (1942): Életem. Szent István Társulat, Budapest.

Schütz A. (1944): A bölcselet elemei. 3. kiadás. Szent István Társulat, Budapest.

Sexton, V. S., Misiak, H. (1966): Catholics in Psychology. Grune and Stratton, New York.

Köszönetnyilvánítás. Jelen tanulmány alapja az Európai Humán Tudományok Kongresszusán (ESHS) Barcelonában, az Autonóm Egyetemen 2002. augusztus 12-én elhangzott előadás. Ennek megtartásában nagy segítségemre volt Robert Kugelmann meghívása és biztatása a szimpóziumon való részvételre. Kiutazásomat a Collegium Budapest támogatta, melynek a 2001/2002-es tanévben tagja voltam. 


\section{PLÉH, CSABA \\ THE CATHOLIC TRADITION AT THE BEGINNINGS OF HUNGARIAN PSYCHOLOGY: HARKAI, DIENES, SCHÜTZ}

On the basis of an analysis of early 20th Century Hungarian psychologist form a Catholic background the paper argues that Hungarian psychologists did not represent a unified version of so called 'Catholic psychology'. Rather, they approached issues of scientific psychology from different perspectives. At the same time all believed in the independence of professional psychology, and in a modernizing attempt a combination of functionalism and an Aristotelian interpretation of mind, an emphasis on the study of thought processes and integrative aspects of personality, and a practical functionalism which is involved in educational reforms. The different political and intellectual Catholic trends found their place within Catholic psychology. It is an important message even for our contemporary concerns that these authors did not see any necessary contradictions between their personal Catholic belief, and even Catholic roles and advocating modern psychology, even in its experimental variety. Different individualities and value engagements do appear in the different alternatives even within the Catholic camps.

Keywords: Catholicism, functionalism, thought psychology 